\title{
THREATENED FISHES OF THE WORLD: Hucho taimen (Pallas, 1773)
}

\author{
Chang-an Wang ${ }^{1,2}$, Qi-you Xu ${ }^{* 1}$, Jia-sheng Yin ${ }^{1}$, Jin-nan Li $^{1}$, Lian-sheng Wang ${ }^{1}$, Zhi-gang \\ Zhao ${ }^{1}$, Liang Luo ${ }^{1}$, Jian-zhang $\mathrm{Ma}^{2}$
}

${ }^{1}$ Heilongjiang River Fishery Research Institute, Chinese Academy of Fishery Sciences, Harbin 150070, China

${ }^{2}$ College of Wildlife Resources, Northeast Forestry University, Harbin 150040, China

* Corresponding Author, E-mail: gordoncase@126.com

\begin{tabular}{|c|c|}
\hline ARTICLE INFO & ABSTRACT \\
\hline Received: 3 April 2014 & Taimen Hucho taimen (Pallas, 1773) was once common in Chi- \\
\hline Received in revised form: 29 June 2014 & na, Russia, Kazakhstan and Mongolia but is disappearing now from \\
\hline Accepted: 5 July 2014 & its native region. This vulnerable species has considerable eco- \\
\hline Avaible online: 28 August 2014 & $\begin{array}{l}\text { logical importance but there are few data available on its biol- } \\
\text { ogy. The limited available data on its systematics, distribution, ecol- } \\
\text { ogy, reproduction and threats are summarized and discussed. }\end{array}$ \\
\hline \multicolumn{2}{|r|}{ 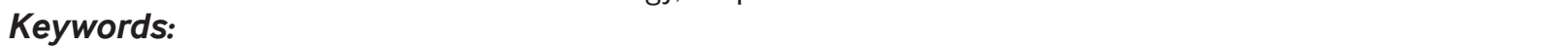 } \\
\hline \multicolumn{2}{|l|}{ Hucho taimen } \\
\hline \multicolumn{2}{|l|}{ Salmonidae } \\
\hline \multicolumn{2}{|l|}{ Conservation } \\
\hline Threatened fish & \\
\hline
\end{tabular}

\section{COMMON NAMES}

Taimen (China, Kazakhstan, Mongolia, Russian Fed, USA, Sweden, etc.); Taimenlaks (Denmark). The species is also known as Siberian taimen, Mongolian taimen and Siberian salmon (Fig 1).

\section{CONSERVATION STATUS}

Vulnerable A2bcd in China, Russia, Kazakhstan and Mongolia, and is being considered for listing in the International Union for Conservation of Nature (IUCN) Red List (Wang and Xie, 2004; Matveyev et al., 1998; Baasanjav and Tsend-Ayush, 2001). So far, it has just been listed as vulnerable in the IUCN Red List in 2012.

\section{IDENTIFICATION}

Body elongate and slightly compressed. Mouth terminal and slit large, praemaxilla reaching the rear edge of the eyes. Maxilla, lower jaw, vomer, palatine and tongue with sharp teeth. Scales oval, minute, without radial grooves and rings extremely clear. There are 173-288 scales in a midlateral row (107-164 pored scales). Adipose fin is welldeveloped. Body color dark green on back and belly silvery

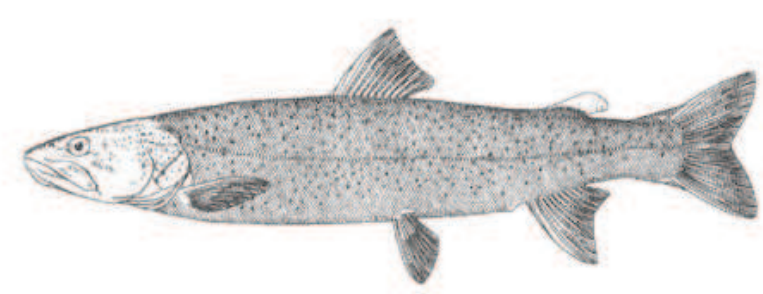

Fig 1. Hucho taimen in River (Yue and Chen, 1998)

white. Some small cross-shaped dark spots on head and flanks. Pelvic fin carmine red, anal fin and caudal fin appear in the adult, likewise, but only during the spawning period. The number of pyloric caeca varies from 205 to 219 (Zhang, 1995; Yue and Chen, 1998).

\section{DISTRIBUTION}

In China, it is distributed in the river systems of the Amur River, Wusuli River, Tumen River, Songhua River, Irtysh River and Hanasi Lake. In Russia, it is distributed in the upper reaches of the Volga and Ural rivers (Yue and Chen, 1998). In Mongolia, it is distributed in rivers throughout Siberia and northern Mongolia (Esteve et al., 2009). 


\begin{abstract}
ABUNDANCE
It has an estimated area of occupancy of $12,404,332 \mathrm{~km}^{2}$ (including the entire watershed area). The total range area lost is estimated to be $444,972 \mathrm{~km}^{2}$ (Hogan and Jensen, 2013). It was estimated that there was a total natural range reduction of $3.6 \%$. Loss in the range area for specific regions varies from $3.2 \%$ within Russia (in the Volga, Ural and Pechora Rivers), 6.9\% within China (in the Amur River basin) and $19.1 \%$ within Mongolia (Hogan and Jensen, 2013).
\end{abstract}

\section{HABITAT AND ECOLOGY}

Inhabits the fast-flowing streams below $15^{\circ} \mathrm{C}$. In order to overwinter, it gradually moves into large rivers or deeper waters in the neighboring areas before ice is formed. It feeds mainly on other fishes. Sometimes, it also preys on snakes, frogs, rodents and aquatic birds (Yue and Chen, 1998). Maturity is reached at age 5 (Yue and Chen, 1998). After the ice melts, when the temperature range is $8-10^{\circ} \mathrm{C}$, matured parent fish excavate nests. They spawn in the section of rivers with rapid flow and gravel bottom, and have the habit of burying and protecting eggs (Zhang, 1995).

\section{THREATS}

The main factor is poaching in the spawning period which has significant influence on declining of populations. Water pollution by wastewater from mining and factories along the river is another important factor.

\section{CONSERVATION ACTION}

No protective measures are in place except that it was listed as a protected wild animal in China (Wang and Xie, 2004).

\section{CONSERVATION RECOMMENDATIONS}

Fishing must be prohibited during the spawning migration in the spring and the pollution of rivers must be stopped in order to improve the habitat of the fish (Wang and Xie, 2004). Ban illegal fishing methods. A recovery plan should be implemented immediately. Feeding and breeding has been successfully made in the Heilongjiang River Fisheries Research Institute. Further studies on its ecology, nutrition, disease and reproductive biology are needed.

\section{ACKNOWLEDGEMENTS}

This study was supported by the Special Fund for Agroscientific Research in the Public Interest (201003055) and National Key Technology Research and Development Program in the 12th Five year Plan of China (2012BAD25B10).

\section{Sažetak}

\section{UGROŽENE VRSTE RIBA U SVIJETU: Hucho taimen (Pallas, 1773)}

Taimen Hucho taimen (Pallas, 1773) je nekoć bio čest u Kini, Rusiji, Kazahstanu i Mongoliji, ali sada nestaje iz svojih prirodnih staništa. Ova osjetljiva vrsta ima značajnu ekološku važnost iako ima malo podataka o njenoj biologiji. Dostupni podaci vezani uz sistematiku, distribuciju, ekologiju, razmnožavanje i prijetnje su ograničeni te su sažeti i o njima se raspravlja.

Ključne riječi: Hucho taimen, Salmonidae, zaštita, ugrožene vrste

\section{REFERENCES}

Baasanjav, G., Tsend-Ayush, A. (2001): Mongol Orny Zagas (Fish of Mongolia). Ulaanbaatar: ADMON Publishing Company, 385pp.

Esteve, M., David G., Deborah A. M. (2009): Spawning behaviour of taimen (Hucho taimen) from the Uur River, Northern Mongolia. Environmental biology of fishes, 84, 2, 185-189.

Hogan, Z., Jensen, O. (2013): Hucho taimen. In: IUCN 2014. [cited 2014 April 6]. Available from: http://www.iucnredlist.org

Matveyev, A. N., Pronin, N. M., Samusenok, V. P., Bronte, C. R. (1998): Ecology of Siberian taimen Hucho taimen in the Lake Baikal Basin. Journal of Great Lakes Research, 24, 905-916.

Wang, S., Xie, Y. (2004): China species red list (vol. 1, red list) (in Chinese). Beijing, Higher Education Press. 166pp.

Yue, P., Chen, Y. (1998): China red data book of endangered animals. Beijing, Science Press. 29-31pp.

Zhang, J. (1995): The fishes of Heilongjiang, China (in Chinese). Harbin, Heilongjiang Press of Science and Technology. 50-52pp. 